\title{
DEVELOPING STUDENTS' INTERCULTURAL COMMUNICATIVE COMPETENCE IN FOREIGN LANGUAGE CLASSROOM
}

\author{
Oksana Bahlai ${ }^{1}$ (corresponding author), \\ Nataliya Machynska ${ }^{2}$, Yuliia Matviiv-Lozynska ${ }^{3}$, Olha Senkovych ${ }^{4}$, Mariia Voloshyn ${ }^{5}$ \\ ${ }^{1,3,4,5}$ Lviv Polytechnic National University, Ukraine \\ ${ }^{2}$ Ivan Franko National University of Lviv, Ukraine \\ oksanabaglay@yahoo.com
}

\begin{abstract}
Current social and economic changes have significantly influenced the tourism industry worldwide turning it into a diversified sphere of activity aimed at servicing tourists and meeting their needs. As tourist travels continue to grow throughout the world, they cause extensive cross-cultural contacts between different language and cultural groups. Thus, higher educational establishments of tourism profile have an important task to train competent specialists able to interact effectively at the intercultural level. In our article, based on the experience of teaching master's degree students majoring in international tourism at Lviv Polytechnic National University, we analysed possibilities of ICC development in ESP classes by means of flipped classroom method, role plays, discussions and a special course "Cross-cultural communication in religious tourism" designed by the authors. As shown by the results of our study, the methods and resources used in our ESP classes may be particularly appropriate for the development of students' ICC because they provide the basis for intercultural communication, ensure the link between the learning and real life and thus make the development of ICC more meaningful to learners.
\end{abstract}

Keywords: international tourism students; intercultural communicative competence; ESP; flipped classroom; role plays; discussions.

\section{Introduction}

Current social and economic changes have significantly influenced the tourism industry worldwide turning it into a diversified sphere of activity aimed at servicing tourists and meeting their needs. At the beginning of the 21st century, special attention is paid to the education, aimed at preparing an individual for functioning in a multicultural society. It involves the ability to use more than one language as well as to cooperate with the representatives of different cultures, nationalities, and religions from different social environments. According to the data of World Travel \& Tourism Council report (2018), tourism generated $118,454,000$ jobs in 2017 (3.8\% of total employment) in hotels, restaurants, travel agencies, airlines worldwide and it was forecast to grow by $2.4 \%$ in 2018. In addition, the World Tourism Organisation (UNWTO) foresees that the number of international tourist arrivals in the world will increase to 1.6 billion people by 2020. As tourist travels continue to grow throughout the world they cause extensive cross-cultural contacts between different language and cultural groups. Modern labour markets of highly developed countries pose immensely high requirements to the specialists in any branch of economy, tourism in particular. A current employer searches for an employee fluent in one or even more foreign languages. Consequently, the increase in the number of tourist arrivals results in the need of highly qualified employees capable of providing all necessary services at the workplaces. Thus, higher educational establishments of tourism profile have an important task to train competent tourism specialists able to interact effectively at the intercultural level. In this regard, the aim of this paper is to analyse methods for the development of intercultural communicative competence (ICC) of international tourism students by means of ESP.

\section{Theoretical background}

The analysis of works has shown that there is no single definition of the term "competence". Raven (2002) believes that competence is a special ability of a person necessary to carry out any activity effectively that requires specific professional knowledge and skills in a discipline as well as realisation of the responsibility for the outcomes. Fedoruk (2015) treats competence as a personal characteristic which integrates knowledge, skills and attitude of an individual aimed at achieving a particular goal. Mulder (2012) states that this term can be treated as an ability to apply knowledge and skills at a certain level of independency and autonomy. Chistyakova (2016) determines competence as a set of functions, abilities and knowledge combined to carry out a specialist's duties at work. While a variety of definitions of the term "competence" have been suggested, this paper will define this concept as a holistic system, a set of properties, qualities and states of an individual necessary for an effective performance of professional activity. 
When speaking about intercultural competence we can use the research of Taylor (1994) who treats this notion as a transformational process in which a person develops adaptive ability changing his/ her lifestyle for effective understanding and adaptation to the requirements of another culture. In this sense, intercultural competence is not a result, instead, it is considered to be a constant internal personal process. As stated by Yaksa (2008), intercultural competence is the availability of knowledge, skills and abilities used in the process of communication by people from different cultures. The author defines intercultural competence as a combination of knowledge of a person's cultural identity, his / her customs and traditions which can be applied in the process of communicative interaction with the culturally different people and helps an individual to form a model of behaviour that is acceptable in communicating with representatives of other cultures" (Yaksa, 2008, p. 372). Sercu (2004) focuses on the fact that the development of intercultural competence is very complicated in view of affective, cognitive and behavioural factors that are of high importance in this process.

In fact, the communicative component of intercultural interaction implies the exchange of information, knowledge, ideas as well as actions, perceptions of the participants of communication, exchange and establishment of mutual understanding between them. In the context of intercultural interaction, the significance of the perceptive component is constantly growing, as while perceiving other people, every person uses the images that were formed in his / her imagination in the past, which facilitates the process of communication.

It should be stressed that tourism is one of the most important channels of intercultural communication. Naturally, every international tourist represents a specific nation, culture, mentality. In fact, each tourist trip has an integrated goal, for instance, having a rest in a foreign country that entails simultaneous acquaintance with the culture and history of this country, an expansion and deepening of channels of cultural communication. In this case, as stated by Rozkwitalska (2017), knowledge about the relationship between cultural background and communication increases person's sensitivity in the interaction with individuals from another culture.

Naturally, the way learners study any foreign language unconditionally involves their understanding and knowledge of their own language and culture (i.e., literature, geography, history, arts). In this regard, it is of utmost importance for teachers to teach their students to live and work in two cultures and act as mediators between two "cultural and linguistic contexts, using one's intercultural skills and attitudes" (Byran \& Wagner, 2018, p. 145). Thus, we can assume that the knowledge and skills of intercultural communication by means of ESP is a key component of international tourism specialists' training. Accordingly, the intercultural communication is a purposeful contact between culturally different people or groups of people, due to which the exchange of information, cultural and spiritual values takes place with consideration of the uniqueness and identity of each separate culture. In this regard, it can be noted that ICC becomes a background for an intensive interaction and communication between representatives of different societies. It depends on the quality of preparation for intercultural communication and requires the knowledge of the differences in the needs of different categories of tourists. In view of all that has been mentioned so far, we determine the structure of ICC as comprising the following components: motivational, cognitive, operational and reflexive. The motivational component is a system-forming factor of ICC, since the process of preparation of future international tourism specialists for intercultural communication strongly depends on the level of a person's motivation. The cognitive component involves students' mastering of cultural and ethnocultural terminology, history, language, customs, traditions and features of the native culture and cultures of other countries, the behavioural norms and rules and the specifics of their manifestation in different nations. The operational component of the ICC covers the abilities and skills of intercultural communication which manifest themselves in the behaviour of the participants of this process; reflexive attitude to intercultural knowledge; ethical tactics of interpersonal interaction regarding the emergence and overcoming of barriers in communication with the representatives of other cultural groups; methods and techniques aimed at the achievement of effective communication. The reflexive component of competence implies a generalised self-evaluation and self-improvement of a person's intercultural activity.

\section{Methods}

The study was conducted in the $2^{\text {nd }}$ semester of 2017-2018 academic year and involved 37 master's degree students majoring in international tourism from Lviv Polytechnic National University. The ICC of the students was developed in ESP classes with the use of interactive teaching methods such as flipped classroom, role plays and discussions as well as a special course "Cross-cultural communication in religious tourism". During the study, we used the observation method which helped to collect information. At the end 
of the study, we used a questionnaire to identify students' attitudes towards the use of the special course. The questionnaire included two questions:

1. Did you like the course? If yes, what particularly did you like about it?

2. What difficulties did you have in learning the course?

When we used the flipped classroom method the learners were provided with video-recordings or listener instructed podcasts to be seen or listened to at home and then to be used during the in-class time for the activities aimed at the development of their communicative skills while solving professionally-oriented problems. This method allowed us to use the in-class time mainly for the practical application of knowledge the students obtained out-of-class. For example, while studying the topic "The fundamentals of business communication in Tourism" the students watched videos on the Moodle platform and in YouTube, used such internet resources as Rick Steves' Europe - Travel Guide, Hospitality School Tutorials, BBC Learning English, Ted Talks culture videos.

Role plays were used in our flipped learning when studying the topics "Dealing with complaints: Customer is always right", "At a hotel reception", "Booking a room", "At the airport: lost luggage", "Business communication: cultural aspect in business communication". They gave the students an opportunity to implement already learnt information in close to life professional situations, play the roles of different people to look at a situation from different perspectives.

In our ESP classes we also widely used the discussion method to develop the ICC in international tourism students. Discussions involve students' sharing of their opinions. The main benefit of this method is an immediate application of the newly learnt information and the participation of each student, even those who are usually unwilling to speak up. At home, students watched a video, for example, "Tibetan EcoTourism Initiative" and completed a quiz on the video comprehension. In class, they were provided with handouts on the topic "Local tourism initiatives" which included the information on the tourist attractions in the locality, a list of the main discussion points and functional language to use. Such discussions are very productive as they promote the development of students' soft skills, in particular, the ability to speak in public and collaborate with others.

To develop the ICC in students studying international tourism we also developed a special course "Cross-cultural communication in religious tourism" with the use of interactive ESP methods, presentations and discussions. The course was aimed at the study of theoretical, methodological and practical aspects of the functioning and development of religious tourism as a specific form of intercultural communication. It covers 16 hours of classroom and 6 hours of independent students' work and includes three topics focused on specific features of the organisation of religious tourism and the main pilgrimage routes worldwide and in Ukraine.

The topics were arranged around the barriers in intercultural communication of human communities in religious tourism and the specifics of arrangement of religious tours, including the development of tourist routes, booking the accommodation, provision of catering and entertainment, reservation of airline tickets. The implementation of the course gave the learners an opportunity to widen a range of skills, in particular, to learn how to organise homogeneous groups of people with consideration of the purpose of a religious trip and to assure that travellers with different religious beliefs, cultural values, norms of behaviour and psychological motives for travelling avoid misunderstandings while communicating with each other. The learners were proposed to analyse the existing religious tours developed by the pilgrimage travel centre "Rafail" (in Lviv, Ukraine) in order to improve them using the knowledge and skills they obtained while studying the course. Finally the students, in groups, made presentations of the improved tours where changes were made in the existing routes, taking into account the special wishes of pilgrims. Profound information was provided on each destination, accommodation, catering, entertainment as well as geography of the places, customs of the local people, their cultural background.

\section{Results and discussion}

At the end of the study, the students answered two questions in the questionnaire and thus expressed their attitudes towards the use of the special course "Cross-cultural communication in religious tourism". When answering question 1 ("Did you like the course? If yes, what particularly did you like about it?") all the respondents highly appreciated the course and found some positive aspects of this resource. Most (28) students noted that it promoted their interest in cultures of other nations, 24 of them simultaneously mentioning that they got more interested in the culture of their own country as well. 19 respondents stated that they became more aware of the problem of cultural and religious differences. 17 students liked the course because they had many opportunities to communicate in English. Among other positive aspects of the course mentioned in the answers were interesting content materials, particularly, videos (9 persons); work in 
groups ( 7 persons); tasks which demand creative solutions (5 persons); cultivation of an atmosphere of tolerance (2 persons).

When answering question 2 ("What difficulties / problems did you have in learning the course?") almost half of the students (16) wrote that they did not have any difficulties at all. Among the most commonly mentioned problems were: self-discipline (6 students could not always organise themselves to do the tasks in time), lack of time ( 5 students said that the tasks were time-consuming and they did not have enough time to do them), language proficiency (4 students stated that they were not proficient in English enough to communicate fluently), understanding of the tasks ( 2 students sometimes could not understand what they had to do), problems with technologies (2 students did not always have access to videos).

The observation of the students during the study of the special course "Cross-cultural communication in religious tourism" showed that it raises students' motivation to intercultural communication and helps provide a reflexive analysis of their communicative abilities, offers possibilities to apply the new and earlier acquired knowledge, skills and experience of intercultural communication in close to real life situations.

The process of making a presentation promoted the development of the students' cooperative skills, ability to work in a team and responsibility for the common result. While debating, students could participate in discussions concerning any possible cultural misunderstandings and the ways of their prevention and overcoming. The course not only contributed to the enhancement of ICC of the international tourism students, but also to the development of their creativity, better motivation and interest both in their own culture and the culture of other countries. It raises the awareness of the importance of intercultural competence development by means of ESP as a factor of their successful job performance in the future.

Based on our observation of students while using flipped classroom method, we can conclude it helps to develop students' intercultural communicative competence by means of promoting their self-organisation and self-directedness, ability to adapt to particular situations and different learning modes, to think critically and solve problems. In this, the results of our research confirm those of Strayer (2007) who argues that flipped learning helps students become more aware of their own learning processes. We also totally agree that one of the main advantages of this technology is that less time is spent on lecturing, "using classroom time to answer questions students have about the basic material, ... working on activities that create a learning environment of collaboration with peers" (Ahmad, 2016, p.168). Thus, the in-class time can be used to promote the efficiency of the learning process by encouraging effective interactions between the students and the teacher (Kuzminska, 2016).

Positive results were also provided by the use of role plays and discussions. We could observe that most students were enthusiastic to immediately apply the content material they had learnt into real-world situations. When performing the assigned roles and communicating with peers they demonstrated the decision making and critical thinking skills. Students' behaviour also showed that they were interested and engaged in learning. We find these methods especially proper for the development of students' intercultural communicative competence as they create the basis for communication and interaction, provide a real-like context for classroom practice.

Competence in language and culture provides a learner with the opportunity to realise the values of their own and other cultures, in particular, people's customs, traditions, ways of thinking and acting. ESP in the process of professional training serves as a means of communication between representatives of different cultures. Consequently, it provides the learners with the skills, attitudes and knowledge necessary for such interaction.

\section{Conclusions}

As shown by the results of our research, the intercultural communicative competence of international tourism students can be effectively developed in ESP classes with the use of interactive teaching methods such as flipped classes, role plays and discussions, which are particularly advantageous because they provide the basis for intercultural communication, ensure the link between the learning and real life and thus make the development of ICC more meaningful to learners. The special course "Cross-cultural communication in religious tourism" which was created by us to develop ICC in students studying international tourism also showed its efficiency due to the use of interactive ESP methods, presentations and discussions.

Though the findings of this study have a number of implications for current educational practice, they do not claim to cover the full scope of the problem. Among the prospective areas of further research can be the investigation of the international educational experience of ICC development by means of extracurricular activities. 


\section{References:}

Ahmad, S. (2016). The flipped classroom model to develop Egyptian EFL students' listening comprehension. English Language Teaching, 9, 166-178. http://dx.doi.org/10.5539/elt.v9n9p166.

Byram, M., \& Wagner, M. (2018). Making a difference: Language teaching for intercultural and international dialogue. Foreign Language Annals, 51, 140-151. https://doi.org/10.1111/flan.12319.

Chistyakova, T. B. (2016). Elektronnaya obrazovatel'naya sreda dlya kompetentnostno-oriyentirovanogo obucheniya spetsialistov inzhenernogo profilya [Electronic educational environment for competence-oriented training of engineering specialists]. Nauka i Obrazovaniye. MGTU im. N.E. Baumana, 7, 230-241. Retrieved November, 15, 2018, from http://technomag.edu.ru/doc/845179.html

Fedoruk, H. M. (2015). Formuvannia informatsiino-komunikatsiinoi kompetentnosti maibutnikh uchyteliv tekhnolohii u protsesi profesiinoi pidhotovky [Formation of information and communication technologies competence of future teachers in the course of vocational training]. (Unpublished doctoral dissertation). Mykhailo Kotsiubynsky Vinnitsa State Pedagogical University, Vinnytsia, Ukraine.

Kuzminska, O. (2016). Perevernute navchannia: practychnyi aspect [Flipped learning: practical aspect]. Informatsiini tekhnolohii $v$ osviti, 2, 86-98. https://doi.org/10.14308/ite000574

Mulder, M. (2012). European vocational education and training. In J. P. Wilson (Ed.), Human Resource Development: Learning, Education and Training (pp. 155-175). London: Kogan Page.

Raven, D. (2002). Kompetentnost v sovremennom obshchestve: vyiavlenie, razvitie, realizatsia [Competence in modern society: identification, development, realisation]. Moscow, Russia: Cogito-Tsentr.

Rozkwitalska, M. (2017). Cognition of the multicultural work environment in multinational corporations and intercultural interaction outcomes. In M. Rozkwitalska, Ł. Sułkowski, S. Magala (Eds.), Intercultural interactions in the multicultural workplace: traditional and positive organizational scholarship (pp. 37-51). https://doi.org/10.1007/978-3-319-39771-9_3.

Sercu, L. (2004). Assessing intercultural competence: a framework for systematic test development in foreign language education and beyond. Intercultural education, 15, 73-89. https://doi.org/10.1080/1467598042000190004

Strayer, J. (2007). The effects of the classroom flip on the learning environment: A comparison of learning in a traditional classroom and a flip classroom that used an intelligent tutoring system. Unpublished doctoral dissertation. The Ohio State University, Columbus, Ohio, USA.

Taylor, E. (1994). Intercultural competency: A transformative learning process. Adult education quarterly, 44 (3), $154-174$.

World Travel \& Tourism Council (WTTC). (2018). Travel \& Tourism, Economic Impact 2018, World. London, UK. Retrieved November, 15, 2018, from https://www.wttc.org/-/media/files/reports/economic-impact-research/regions2018/world2018.pdf.

Yaksa, N. (2008). Profesiina pidhotovka maibutnikh uchyteliv: Teoriia i metodyka mizhkulturnoi vzaiemodii v umovakh Krymskoho rehiony [Professional training of future teachers: Theory and practice of intercultural interaction in Crimea region conditions]. Zhytomyr, Ukraine: I. Franko Zhytomyr State University Publishing House. 